\title{
Permasalahan Pelaksanaan Lelang Eksekusi Putusan Pengadilan Dalam Perkara Perdata dalam Praktik
}

\author{
Depri Liber Sonata
}

Dosen Bagian Hukum Keperdataan Fakultas Hukum Universitas Lampung

\begin{abstract}
Abstrak
Berbeda dengan pelaksanaan putusan pengadilan pada perkara pidana yang bersifat aktif maka pelaksanaan putusan pengadilan (eksekusi) pada perkara perdata lebih bersifat pasif, dalam arti bahawa pelaksanaannya sangat tergantung dari upaya proaktif pemohon eksekusi untuk melakukan permohonanpermohonan pada setiap tahap pelaksanaan eksekusi kepada Ketua Pengadilan Negeri tempat dimana perkara yang bersangkutan telah diputus dan telah berkekuatan hukum tetap. Dengan demikian pengetahuan mengenai prosedur pelaksanaan eksekusi di bidang perdata sangat penting untuk dipahami khususnya oleh masyarakat pencari keadilan yang mengalami kesulitan/permsalahan terhadap pemenuhan amar putusan yang telah berkekuatan hukum tetap, baik eksekusi terhadap pembayaran sejumlah uang yang melalui tahapan pelaksanaan lelang eksekusi, maupun terhadap eksekusi riil. Permasalahan hukum yang paling sering ditemui terkait pelaksanaan eksekusi perdata adalah pada tahapan lelang eksekusi, dimana sulitnya menjual objek lelang eksekusi yang disebabkan oleh berbagai faktor. Permasalahan lain yang tidak kalah pentingnya adalah pada tahap eksekusi riil/pengosongan objek eksekusi yang sering menimbulkan konflik sosial dan tidak jarang berakhir dengan tindakan-tindakan yang dapat dikualifikasikan sebagai kejahatan (tindak pidana). Penelitian ini membahas mengenai prosedur dan permasalahanpermasalahan beserta solusi yang dapat ditempuh terkait permasalahan pelaksanaan eksekusi perdata di dalam praktik.
\end{abstract}

Kata Kunci: Hukum Acara Perdata, Eksekusi Perdata, Lelang Eksekusi

\section{Pendahuluan}

Eksistensi dan independensi lembaga peradilan di suatu negara sejatinya adalah sebagai perwujudan dari penegakan prinsip negara yang memiliki konsep negara hukum (rule of law) sebagai cita bangsanya, ${ }^{1}$ dimana peranan lembaga peradilan begitu penting dan disejajarkan

1 A. Muhammad Asrun. Krisis Peradilan; Mahkamah Agung dibawah Soeharto. (Jakarta: ELSAM, 2003). hlm. xiv. dengan kedudukan lembaga eksekutif dan legeslatif. Sementara itu, prinsip peradilan sederhana, cepat, dan biaya ringan sebagaimana diamanatkan Pasal 4 Ayat (2) UU No. 48 Tahun 2009 Tentang Kekuasaan Kehakiman ${ }^{2}$ terus dipertanyakan oleh masyarakat pencari keadilan. Masih banyak tantangan yang harus dihadapai oleh lembaga peradilan di Indonesia,

\footnotetext{
${ }^{2}$ Lembaran Negara RI No. 157 Tahun 2009, Tambahan Lembaran Negara RI 5076
} 
terutama mengenai pelaksanaan proses peradilan yang bebas dari suap, keberpihakan, dan praktikpraktik mafia peradilan lainnya yang sulit dibendung, hingga tantangan peningkatan kualitas sumberdaya manusia para hakim yang harus selalu mengikuti perkembangan masalah-masalah hukum kontemporer.

Kepercayaan masyarakat terhadap lembaga peradilan tidak terlepas dari penegakan hukum yang adil dan berkeadilan. Secara garis besar terdapat tiga syarat yang mempengaruhi terwujudnya penegakan hukum yang adil atau berkeadilan, yaitu: ${ }^{3}$ Pertama, mengenai aturan hukum yang akan ditegakkan, dimana penegakan hukum yang adil akan tercapai apabila hukum yang akan ditegakkan, demkian pula hukum yang mengatur cara-cara penegakan hukum (hukum acara) adalah benar dan adil; kedua, peran pelaku penegak hukum yang baik, hal ini mengingat di tangan para pelaku penegak hukum inilah hukum yang abstrak menjdi konkrit; ketiga, lingkungan sosial tempat dimana hukum itu berlaku, artinya hukum, baik dalam proses pembentukan maupun dalam penegakkannya tidak terlepas dari pengaruh sosial, ekonomi dan budaya masyarakat.

Dipihak lain, proses penegakan hukum materil tidak dapat dipisahkan dengan penegakan hukum formil (hukum acara), karena keduanya berjalan sebagai sebuah

\footnotetext{
3 Bagir Manan. Sistim Peradilan Berwibawa; Suatu Pencarian. (Yogyakarta: UII Press, 2005).hlm. 9-12. bandingkan dengan teori legal system yang dikemukakan Friedmen seorang sarjana hukum amerika yang dipengaruhi pemikiran sociological jurisprudence.
}

sistem yang tujuannya tidak lain adalah untuk mewujudkan rasa keadilan kepada masyarakat dimana hukum ini diterapkan. Demikian halnya dengan penegakan hukum perdata dan acara perdata, dimana hasil akhir dari rangkaian proses penyelesaian sengketa perdata bukan hanya pada tercapainya suatu putusan yang telah memperoleh kekuatan hukum tetap, melainkan juga pada proses pelaksanaan putusan pengadilan oleh para pihak yang bersengketa secara sukarela. Namun kenyataannya tidak sedikit ditemui bahwa pihak yang dinyatakan kalah dan/atau dihukum untuk melaksanakan amar putusan yang telah mempunyai kekuatan hukum tetap tidak secara sukarela atau tidak menunjukan itikad baik untuk itu. dengan demikian lembaga eksekusi menjadi upaya terakhir yang harus ditempuh oleh pihak yang dimenangkan dalam proses persidangan demi mendapatkan pemenuhan hak-haknya sebagaimana yang tertuang pada amar putusan pengadilan yang telah berkekuatan hokum tetap.

Pemahaman terhadap ruang
lingkup dan permasalahan-permasalahan eksekusi perdata sangat penting dikuasai oleh para praktis hukum, mengingat eksekusi perdata tidak hanya berkaitan dengan bidang hukum perdata melainkan juga pelaksanaan putusan perkara kepailitan oleh Pengadilan Niaga, Pengadilan Agama, bahkan terhadap pelaksanaan putusan lembaga arbitrase nasional maupun asing di Indonesia.

Penegakan hukum eksekusi pengadilan dalam perkara perdata melibatkan peran tiga lembaga yaitu: Pengadilan Negeri, Kantor 
Pelayanan Kekayaan Negara dan Lelang (KPKNL), dan Kepolisian Negara RI (POLRI). Meskipun lembaga yang di sebut terakhir ini tidak mutlak namun peranannya justru tidak kalah penting, mengingat dalam praktek tidak sedikit ditemui upaya perlawanan dari pihak tereksekusi yang disertai kekerasan, ancaman, dan pengerahan massa yang brutal. Permasalahan lain yang mungkin muncul adalah sulitnya mencari peminat objek lelang pada saat dilaksanakan lelang eksekusi, yang berakibat pada terhambatnya pemenuhan hak pemohon eksekusi yang telah dimenangkan pengadilan melalui putusan pengadilan yang telah mempunyai kekuatan hukum tetap. Hal lain yang mungkin muncul adalah penundaan eksekusi yang disebabkan oleh perbedaan penafsiran mengenai pelaksanaan eksekusi antara para pihak maupun pejabat pelaksana eksekusi di lapangan. $^{4} \quad$ Bahkan penundaan eksekusi disebabkan oleh prilaku aparat penegak hukum yang bersekongkol dengan calon pembeli lelang dalam pelaksanaan lelang eksekusi yang biasanya bertujuan agar objek lelang nilainya menurun dan merugikan pihak tereksekusi.

Fakta mengenai permasalahan diatas merupakan fenomena hukum yang sering terjadi di masyarakat, dengan demikian untuk menghindari asumsi negatif masyarakat pencari keadilan

\footnotetext{
${ }^{4}$ Sebagai contoh kasus adalah eksekusi yang berlarut-larut terkait eksekusi gedung Aspac di Jl,. HR Rasuna Said Kav. X-2 No. 4 Kuningan Jakarta Selatan. Pemohon eksekusi PT. Bumijawa Sentosa dan Termohon eksekusi PT. Mitra Bangun Griya. Wakil Ketua MA diduga Intervensi Penetapan Eksekusi. www.hukumonline.com diakses tanggal 19 Februari 2008.
}

terhadap penegakan hukum di negara yang berdasar atas hukum dan citra peradilan sederhana, cepat, dan biaya ringan, maka penelitian ini menjadi sangat penting untuk dilakukan sebagai upaya untuk lebih memahami prosedur dan permasalahan serta menemukan pemecahan terhadap permasalahanpermsalahan yang terjadi di dalam praktik sebagaimana yang telah diuraikan diatas. khususnya mengenai penggunaan bantuan kekuasan umum (POLRI) dalam hal terjadi perlawanan pihak tereksekusi bahkan perampasan kembali objek eksekusi oleh pihak tereksekusi (pada eksekusi riil) dan permasalahan penjualan objek lelang (pada eksekusi pembayaran sejumlah uang).

\section{Pembahasan}

\section{Pengertian dan Jenis-jenis Eksekusi Perdata}

Pengertian ekseksi atau pelaksanaan putusan pengadilan, ${ }^{5}$ tidak lain daripada melaksanakan secara paksa putusan pengadilan dengan bantuan kekuatan umum apabila pihak yang kalah tidak mau menjalankannya secara sukarela. $^{6}$ Dengan demikian, pada prinsipnya lembaga eksekusi tidak diperlukan andai pada suatu amar putusan pengadilan pihak yang dikalahkan dan di hukum bersedia memenuhinya

\footnotetext{
5 Pemakaian istilah "pelaksanaan putusan" dipergunakan di dalam buku Subekti. Hukum Acara Perdata. (Jakarta: BPHN, 1977. hlm. 128. serta Retnowulan Sutantio dan Oeripkartawinata. Hukum Acara Perdata dalam Teori dan Praktek (bandung: Aumni, 1979). Hlm. 111. sebagaimana dikutip M. Yahya Harahap. Ruang Lingkup Permasalahan Eksekusi Bidang Perdata. ed. II. cet. II (Jakarta: Sinar Grafika, 2006). hlm. 5-6.

${ }^{6}$ M. Yahya Harahap. Loc.cit. hlm. 6.
} 
dengan itikad baik dan secara sukarela.

Ruang lingkup penerapan eksekusi perdata tidak hanya meliputi bidang hukum perdata saja, namun juga dalam bidang hukum kepailitan, ${ }^{7}$ hukum Islam, dan pelaksanaan putusan arbitrase nasional maupun internasional dalam hal objek eksekusinya berada di dalam yurisdiksi hukum Republik Indonesia. ${ }^{8}$ Sedangkan apabila cara menjalankan putusan hakim perdata kita bandingkan dengan cara menjalankan putusan hakim pidana, maka boleh dikatakan bahwa cara menjalankan putusan hakim pidana itu agak mudah, sedangkan cara menjalankan putusan hakim perdata itu agak sulit, dimana pada eksekusi pidana dijalankan oleh jaksa (bersifat aktif), sendangkan eksekusi putusan hakim perdata dilaksanakan oleh panitera atau juru sita atas perintah ketua pengadilan negeri (bersifat pasif). ${ }^{9}$

Pada hukum acara perdata, jenis-jenis eksekusi dibedakan berdasarkan isi dan perintah amar putusan pengadilan yang hendak di eksekusi. Sudikno Mertokusumo berpendapat bahwa eksekusi perdata diklasifikasikan menjadi 4 (empat) jenis, yaitu: ${ }^{10}$

\footnotetext{
${ }^{7}$ Lihat: Pasal 300 UU No. 37 Tahun 2004.

8 Lihat: UU No. 30 tahun 1999 Tentang Arbitrase dan Alternatif Penyelesaian Sengketa.

9 R. Soesilo. RIB/HIR dengan penjelasan (Bogor: Politeia, 1995). hlm. 141. bandingkan dengan: Abdulkadir Muhammad. Hukum Acara Perdata. cet. VII. (Bandung: PT. Citra Aditya Bakti, 2000). hlm. 24-25.

10 Sudikno Mertokusumo, Hukum Acara Perdata Indonesia .ed. V. cet.I. (Yogyakarta: Penerbit Liberty, 1998). hlm.210. Bandingkan juga dengan: Retnowulan Sutantio dan Oeripkartawinata. hlm. 130. membagi 3 (tiga) jenis eksekusi yaitu:
}

1. membayar sejumlah uang (Pasal $196 \mathrm{HIR} / 208 \mathrm{RbG}$ );

2. melaksanakan suatu perbuatan (Pasal 225 HIR/259 RbG);

3. eksukusi riil (Pasal $1033 \mathrm{Rv);}$

4. Parate eksekusi $(1155,1175$ Ayat (2) BW).

Sedangkan Yahya Harahap berpendapat agak berbeda, yaitu bahwa jenis eksekusi melaksanakan suatu perbuatan pengertiannya sama dengan ekekusi riil, sedangkan saat pemenuhannya digantikan dengan pembayaran sejumlah uang. Dengan demikian beliau berpendapat bahwa secara garis besar eksekusi perdata hanya terdiri dari dua jenis eksekusi yaitu: ${ }^{11}$

1. eksekusi riil/tindakan nyata; dan

2. eksekusi pembayaran sejumlah uang.

Meskipun pada prinsipnya
bahwa eksekusi sama-sama
merupakan pelaksanaan putusan
secara paksa (pelaksanaan eksekusi)
namun antara dua jenis eksekusi
sebagaimana tersebut diatas memiliki
perbedaan yang mendasar, yaitu: ${ }^{12}$

1. pada eksekusi riil pelaksanaannya lebih mudah dibandingkan dengan eksekusi pembayaran sejumlah uang, dimana untuk melakukan eksekusi pembayaran sejumlah uang dibutuhkan tahapan sita eksekusi dan penjualan lelang eksekusi.

2. eksekusi riil penerapannya hanya dimungkinkan terhadap putusan pengadilan yang telah memperoleh kekuatan hukum tetap, putusan serta merta, putusan provisi, dan akta

eksekusi pembayaran sejumlah uang, melaksanakan suat perbuatan tertentu, dan eksekusi riil.

${ }^{11}$ M. Yahya Harahap. op. cit. hlm. 23-28.

${ }^{12}$ M. Yahya Harahap. ibid. hlm. 23-28. 
perdamaian yang dibuat dihadapan hakim (dading). Sedangkan pada eksekusi pembayaran sejumlah uang tidak terbatas hanya pada putusan pengadilan sebagaimana tersebut diatas, namun juga dapat didasarkan atas akta-akta tertentu yang didasarkan oleh hubungan hukum utang piutang yang kekuatan pembuktian dan eksekutorialnya dipersamakan dengan putusan pengadilan yang telah mempunyai kekuatan hukum tetap, yaitu: groose akta pengakuan utang, groose akta hipotik (pesawat terbang dan kapal laut), Sertifikat Hak Tanggungan (SHT), dan Sertifikat Jaminan fidusia. Eksekusi terhadap akta-akta sebagaimana tersebut di atas dikenal dengan istilah prate eksekusi, yang biasanya sebagai bukti telah diadakannya hubungan hokum utang piutang yang mempergunakan jaminan kebendaaan tertentu;

\section{Asas-asas Hukum Eksekusi}

\section{Perdata}

a. Asas umum (putusan harus telah mempunyai kekuatan hukum tetap)

Putusan yang telah memperoleh kekuatan hukum tetap (in kracht van Gewijsde) menjadi syarat utama yang harus dipenuhi agar putusan yang akan dimohonkan eksekusi dapat dikabulkan (executable). Dengan demikian putusan yang dapat dilakukan eksekusi hanya didasarkan pada alasan-bahwa putusan tersebut telah memperoleh kekuatan hukum tetap, karena di dalam putusan sebagaiman tersebut didalammya terkandung hubungan hukum yang tetap dan pasti antara para pihak yang berperkara; dan di dalam putusan yang telah memperoleh kekuatan hukum tetap juga terdapat hubungan hukum yang harus ditaati dan meski dipenuhi oleh pihak tergugat, atau secara formil putusan yang telah mempunyai kekuatan hukum tetap memiliki sifat eksekutorial dengan adanya irah-irah "Demi keadilan berdasarkan ketuhanan yang maha esa". ${ }^{13}$

Namun demikian di dalam teori hukum acara perdata khususnya mengenai eksekusi, terhadap asas umum eksekusi tersebut diatas terdapat beberapa pengecualian. Dengan perkataan lain bahwa pada beberapa keadaan tetap dimungkinkan dilaksanakan suatu eksekusi tanpa perlu menunggu adanya suatu putusan yang mempunyai kekuatan hukum tetap terlebih dahulu. Beberapa pengecualian tersebut adalah:

1) Putusan yang dapat dilaksanakan terlebih dahulu;

2) Pelaksanaan putusan provisi;

3) Akta perdamaian;

4) Eksekusi Grosse Akta Hipotik dan Groose Akta Pengakuan Utang;

5) Eksekusi atas Hak Tanggugan dan Jaminan Fidusia

Pada Sertifikat Hak Tanggungan dan Fidusia berlaku juga prinsip parate eksekusi seperti halnya pada groose akta hipotik dan akta pengakuan utang.meskipun di dalam praktek status parate eksekusi tersebut sering tidak konsisten. ${ }^{14}$

\footnotetext{
${ }^{13}$ Sudikno Mertokusumo. op. cit. hlm. 209. bandingkan dengan sifat eksekutorial pada akta perdamaian, groose akta pengakuan hutang, sertifkat hak tanggungan dan Sertifikat jaminan fidusia.

14 Ny. Arie S. Hutagalung. Praktek Pembebanan dan Pelaksanaan Eksekusi Hak Tanggungan di Indonesia (Jurnal
} 
b. Putusan tidak dijalankan secara sukarela

Sebagaimana telah dijelaskan diatas bahwa pada prinsipnya pelaksanaan putusan pengadilan semestinya dilaksanakan oleh pihak tergugat yang kalah dengan sukarela. Namun apabila tindakan tersebut tidak dilaksanakan, maka pelaksanaan suatu putusan pengadilan dilakukan dengan upaya paksa dan bila perlu menggunakan kekuatan umum. Dengan kata lain bahwa eksekusi tidak diperlukan jika pihak tergugat sudah menjalankan putusan secara sukarela disertai itikad baik.

\section{c. Putusan harus bersifat penghukuman (condemnatoir) \\ Di dalam teori hukum acara} perdata dikenal dua macam putusan pengadilan yaitu: putusan yang bersifat condemnatoir dan putusan yang bersifat declaratoir. Sedangkan dalam kaitannya dengan eksekusi perdata, hanya putusan yang bersifat menghukum (condemnatoir) saja yang dapat dilakukan eksekusi secara paksa, bila perlu dengan memnggunakan bantuan kekuatan umum (POLRI). Sedangkan putusan yang bersifat declaratoir dan constitutif tidak dapat dilakukan eksekusi, karena tidak dimuatnya hak atas suatu prestasi, maka terjadinya akibat hukum tidak tergantung pada bantuan atau kesediaan dari pihak yang dikalahkan, maka tidak diperlukan sarana-sarana pemaksa untuk menjalankannya. ${ }^{15}$

Hukum dan Pembangunan Tahun Ke-38 No. 2. April-Juni 2008). hlm. 148-174

${ }^{15}$ Sudikno Mertokusumo. loc. cit. hlm. 209 d. Eksekusi atas perintah dan di bawah pimpinan Ketua Pengadilan Negeri.

Kewenangan menjalankan eksekusi dimiliki oleh lembaga pengadilan tingkat pertama/pengadilan negeri yang mengadili perkara yang bersangkutan pada tingkat pertama merupakan asas yang penting mengingat permohonan eksekusi yang diajukan terhadap Pengadilan Tinggi dan Mahkamah Agung dapat dikatakan tidak memiliki dasar hukum. Sebagaimana ketentuan Pasal 195 Ayat (1)/ 208 Ayat (1) Rbg menyatakan bahwa: ${ }^{16}$

"Dalam Hal mejalankan putusan pengadilan negeri, dalam perkara yang pada tingkat pertama diperiksa oleh pengadilan negeri maka dilakukan atas perintah dan dengan pimpinan ketua pengadilan negeri yang pada tingkat pertama memeriksa perkara itu...".

\section{Institusi yang terkait dengan Proses Eksekusi Perdata}

Pengadilan Negeri melalui Ketua Pengadilan Negeri, juru sita dan juru sita pengganti, Kantor Penyelesaian Piutang Negara dan Lelang (KPKNL), Kepolisian Negara RI (POLRI).

a. Pengadilan Negeri; ${ }^{17}$

16 R. Soesilo. RIB/HIR dengan penjelasan (Bogor: Politeia, 1995). hlm. 140.

${ }^{17}$ Pasal 197 Ayat (1)/Pasal 209 Ayat (1) Rbg menyatakan bahwa:" Penyitaan dijalankan oleh panitera pengadilan negeri". Dan Pasal 195 Ayat (1) HIR/Pasal 206 Rbg menyatakan bahwa: "Dalam hal menjalankan putusan pengadilan negeri, dalam perkara yang pada tingkat pertama diperiksa oleh pengadilan negeri maka dilakukan atas perintah dan dengan 
b. Kantor Pelayanan Kekayaan Negara dan Lelang (KPKNL) ${ }^{18}$

c. Kepolisian Negara Republik Indonesia (POLRI)

Sebagaimana

telah

disebutkan diatas bahwa eksekusi dapat diartikan sebagai pelaksanaan putusan secara paksa melalui pengadilan dan bila perlu dengan menggunakan kekuatan umum. Sebagaimana Pasal 14 huruf (1) UU No. 2 Tahun 2002 menyatakan bahwa kepolisian negara Republik Indonesia "bertugas melaksanakan tugas lain sesuai peraturan perundang-undangan" selain keempat tugas utama POLRI. Ruang lingkup kewenangan POLRI terkait dengan proses eksekusi perdata tidak terbatas pada:

1) Menjaga barang sitaan (197 Ayat (9) HIR/Pasal 212 Rbg.);

2) menbantu dalam proses pengosongan dan pembongkaran barang sitaan (Pasal 200 Ayat (11) HIR dan Pasal 218 Ayat (2) Rbg);

3) membantu pelaksanaan penyanderaan terhadap pihak debitor/tereksekusi. ${ }^{19}$

Namun ketiga keadaan sebagaimana tersebut diatas yang secara langsung diperintahkan oleh undang-undang yang terkait dengan pelaksanaan eksekusi perdata. Sedangkan yang langsung berkaitan dengan tindak pidana yang terkait dengan eksekusi perdata adalah:

1) Kejahatan terhadap penguasa umum yang berhubungan dengan barang sitaan (Pasal 231 KUHP);

pimpinan ketua pengadilan negeri yang pada tingkat pertama memeriksa perkara itu..."

${ }^{18}$ M. Yahya Harahap, op. cit. hlm. 117.

19 Pasal 214 HIR/Pasal 248 Rbg. “orang yang berutang yang tidak mengajukan perlawanan atau yang perlawanannya ditolak dengan segera harus dibawa kedalam penjara tempat penyanderaan".
2) Kejahatan terhadap penguasan umum yang berhubungan dengan penghinaan terhadap pejabat negara (Pasal 207);

3) Tindak pidana lain yang mungkin dilakukan pihak tereksekusi terhadap pihak pemohon eksekusi seperti: pengancaman, penganiayaan, pembunuhan, penghinaan, perbuatan tidak menyenangkan dll.

\section{Prosedur Pelaksanaan Eksekusi Putusan Pengadilan dalam Perkara Perdata Pada Tahap Pra Lelang di Pengadilan Negeri}

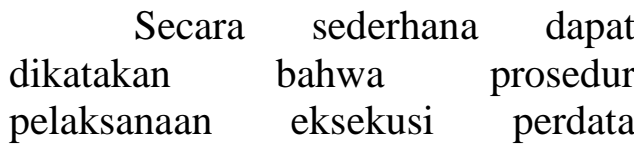
dilaksanakan dengan berpedoman pada asas-asas hukum acara perdata khususnya pada tahapan pelaksanaan putusan/eksekusi, peraturan perundang-undangan yang berlaku, serta melibatkan institusi-institusi terkait. Institusi-institusi sebagaimana dimaksud adalah: Pengadilan Negeri, KPKNL, dan POLRI. Namun, untuk dapat memahami permasalahanpermasalahan sesungguhnya yang sering terjadi di dalam praktek terkait dengan pelaksanaan eksekusi perdata serta akibat hukumnya, maka harus dipahami prosedur pelaksanaan eksekusi secara teoritis yaitu dengan berpedoman kepada peraturan perundang-undangan yang berlaku serta asas-asas hukum acara perdata khususnya yang terkait dengan permasalahan eksekusi.

Pada prinsipnya tahapan pelaksanaan eksekusi putusan pengadilan dalam perkara perdata baik eksekusi riil dan pembayaran 
sejumlah uang adalah sama, kecuali pada tahapan lelang eksekusi yang hanya ditemui pada pelaksanaan eksekusi pembayaran sejumlah uang. Tahapan-tahapan pelaskanaan eksekusi sebagaimana dimaksud adalah sebagai berikut:

\begin{tabular}{llr} 
a. Mengajukan & Permohonan \\
Eksekusi Kepada Ketuan \\
Pengadilan Negeri \\
\multicolumn{2}{c}{ Pelaksanaan eksekusi putusan }
\end{tabular} pengadilan dalam perkara perdata, baik eksekusi riil maupun pembayaran sejumlah uang, harus dilaksanakan atas dasar permohonan dari pihak pemohon eksekusi, permohonan tersebut berbentuk SURAT PERMOHONAN EKSEKUSI yang ditujukan kepada Ketua Pengadilan Negeri tempat dimana perkara yang bersangkutan telah diadili dan diputus sebelumnya. Hal ini tercermin dari asas hukum acara perdata bahwa pada prinsipnya pengadilan (hakim) bersifat pasif, maka atas dasar inisiatif para pihak yang berperkaralah pengadilan (hakim) menjalankan tugasnya dengan berpedoman pada hukum acara perdata yang berlaku. Bahkan di dalam praktek, untuk melanjutkan tahapan demi tahapan pelaksanaan eksekusi, pihak pemohon eksekusi harus aktif melakukan tindakantindakan lanjutan agar proses eksekusi tidak memakan waktu yang terlalu lama. Permohonan sebagaimana dimaksud berbentuk SURAT PERMOHONAN TINDAK LANJUT PELAKSANAAN EKSEKUSI yang disampaikan kepada Ketua Pengadilan Negeri yang memimpin jalannya eksekusi.

b. Peringatan Kepada Tereksekusi untuk Memenuhi Putusan Pengadilan (aanmaning) $\begin{array}{lr}\text { Setelah Ketua } & \text { Pengadilan } \\ \text { Negeri menerima } & \text { SURAT } \\ \text { PERMOHONAN EKSEKUSI, dari } \\ \text { pemohon eksekusi, } & \text { tahapan } \\ \text { selanjutnya adalah Ketua Pengadilan } \\ \text { Negeri }\end{array}$ PENETAPAN AANMANING yang isisnya memerintahkan Panitera atau jika berhalangan dapat menunjuk Juru Sita untuk melakukan pemanggilan terhadap termohon eksekusi untuk hadir dalam sidang Insidentil. Prosedur pemanggilan yang dilakukan oleh Juru Sita tersebut dibuktikan dengan RELAS PANGGILAN AANMANING yang ditujukan kepada baik pemohon maupun termohon eksekusi untuk hadir pada waktu dan tempat yang telah ditentukan. Sedangkan agenda sidang tersebut adalah untuk mengingatkan/menegur termohon eksekusi agar memenuhi amar putusan yang menjadi kewajibannya dalam batas waktu maksimal 8 (delapan) hari, dan jika batas waktu tersebut dilampaui berarti secara definitif tindakan eksekusi dapat dilaksanakan/dilanjutkan ketahap berikutnya, tindakan selanjutnya yang harus ditempuh yaitu Sita Eksekusi dalam hal tidak ada sita jaminan yang telah ditetapkan hakim yang menyatakan sah dan berharga suatu objek sita jaminan tersebut melalui putusan sela dan berbentuk SURAT PENETAPAN SITA JAMINAN, atau sebaliknya jika sita jaminan telah ada maka tahapan selanjutnya adalah Penjualan Lelang Eksekusi. Namun, pada prinsipnya meskipun tenggang waktu tersebut telah lewat, tetap membuka kesempatan kepada termohon eksekusi untuk melaksanakan putusan secara sukarela, sedangkan Ketua Pengadilan Negeri harus menerima keputusan termohon 
eksekusi tersebut demi penegakan hokum yang fleksibel, dan di pihak lain keuntungan bagi termohon eksekusi adalah tidak perlu mengeluarkan biaya-biaya terkait pelaksanaan eksekusi. Pelaksanaan sidang tersebut dibuktikan dengan BERITA ACARA sebagai bukti otentik bahwa telah dilaksanakannya aanmaing oleh Ketua Pengadilan Negeri.

Setelah batas waktu peringatan sebagaimana dimaksud telah dilampaui dan termohon eksekusi tidak juga memenuhi amar putusan secara sukarela atau apabila tidak dipenuhinya panggilan pengadilan oleh termohon eksekusi tanpa alasan yang sah, maka sejak saat itu KPN melaksanakan tindakan lanjutan berupa perintah kepada Panitera atau Juru Sita melalui SURAT PENETAPAN PERINTAH EKSEKUSI atau SURAT PERINTAH PENGOSONGAN untuk melaksanakan eksekusi riil atau pengosongan. Sedangkan pada pelaksanaan eksekusi pembayaran sejumlah uang, KPN melalui SURAT PERINTAH SITA EKSEKUSI memerintahkan Juru Sita untuk melaksanakan sita eksekusi, dalam hal sebelumnya tidak dilakukan sita jaminan terhadap barang-barang milik termohon eksekusi. Pelaksanaan eksekusi riil atau pengosongan dan sita eksekusi, harus dibuktikan dengan berita acara, baik BERITA ACARA EKSEKUSI/PENGOSONGAN maupun BERITA ACARA SITA EKSEKUSI.

Setelah adanya SURAT PENETAPAN SITA EKSEKUSI, pemohon sita eksekusi dibebenkan membayar biaya yang harus dikeluarkan untuk pelaksanaan sita eksekusi dibayar terlebih dahulu, dan nantinya biaya tersebut akan digantikan oleh pihak tersita dalam putusan melalui tagihan tersendiri.

Sebelum sita eksekusi dilaksanakan, Panitera atau Juru Sita membuat SURAT PEMBERITAHUAN bahwa akan dilaksanakannya sita kepada pihak tereksekusi atau ahli warisnya minimal 5 (lima) hari sebelum sita dilaksanakan. Surat sebagaimana dimaksud juga diberikan kepada Lurah/Kepala Desa setempat agar mereka datang menghadiri pelaksanaan sita dan Kepada pihak Kepolisian guna hadir dalam pelaksanaan sita untuk kepentingan pengamanan jalannya proses penyitaan.

c. Status Sita Jaminan yang Dinyatakan Sah dan Berharga menjadi Sita Eksekusi

Berbeda dengan pelaksanaan eksekusi riil, pada eksekusi pembayaran sejumlah uang yang berarti pemenuhan utang/kewajiban yang dapat dinilai dengan uang, maka upaya paksa untuk memenuhi putusan sebagaimana dimaksud dilakukan dengan cara terlebih dahulu menjual secara lelang barangbarang/asset milik termohon eksekusi untuk mendapatkan uang guna pemenuhan kewajibannya sebagaimana yang terdapat pada amar putusan pengadilan yang telah BHT. Namun, sebelum penjualan lelang dapat dilakukan terdapat dua tindakan yang dapat dilakukan oleh Ketua Pengadilan Negeri terkait pelaksanaan eksekusi pembayaran sejumlah uang, yaitu pertama, memerintahkan untuk dilakukan Sita eksekusi dalam hal sebelumnya tidak dilakukan Sita jaminan terhadap barang milik termohon eksekusi, atau kedua adalah langusng menguluarkan SURAT 
PENETAPAN

PENJUALAN

LELANG dalam hal sebelumnya telah dilakukan Sita Jaminan, karena perubahan status Sita Jaminan menjadi Sita eksekusi secara definitif berlaku sejak Putusan yang bersangkutan Berkekuatan Hukum Tetap (BHT).

Dalam hal pelaksanaan Sita Eksekusi, Ketua Pengadilan Negeri melalui SURAT PENETAPAN SITA EKSEKUSI memerintahkan kepada Panitera atau Juru Sita dengan dibantuk 2 (dua) orang saksi melaksanakan sita terhadap barangbarang milik termohon eksekusi bila perlu dengan bantuan aparat kepolisisan, dan pelaksanaan sita eksekusi tersebut dibuktikan dengan BERITA ACARA SITA EKSEKUSI. Setelah sita dilakukan, barang yang menjadi objek sita dititipkan kepada pihak termohon eksekusi, dan tidak boleh dipindahtangankan. Atau kemungkinan lain adalah menyimpan objek sita di tempat yang aman dan disetujui oleh pihak termohon eksekusi dan Lurah/Kepala Desa setempat.

Sedangkan dalam hal seberlumnya telah dilakukan Sita Jaminan terhadap barang-barang milik termohon eksekusi maka, pemohon eksekusi dapat langsung mengajukan SURAT PERMOHONAN TINDAK

\section{LANJUT PELAKSANAAN}

EKSEKUSI yang ditujukan kepada Ketua Pengadilan Negeri setempat, yang berisi permohonan agar KPN segera melaksanakan Lelang Eksekusi terhadap barang-barang yang telah di sita. Berdasarkan surat permohonan tersebut, kemudian KPN mengeluarkan SURAT PENETAPAN PELAKSANAAN LELANG EKSEKUSI yang memerintahkan kepada Panitera untuk mengajukan SURAT PEMBERITAHUAN

PELAKSANAAN LELANG dan SURAT PERMOHONAN LELANG EKSEKUSI yang ditujukan kepada Kepala KPKNL setempat.

\section{Prosedur Pelaksanaan Eksekusi Putusan Pengadilan dalam Perkara Perdata Pada Tahap Pelaksanaan Lelang Eksekusi di KPKNL}

Tahapan selanjutnya dari sita eksekusi dalam proses pelaksanaan eksekusi pembayaran sejumlah uang adalah penjulan di muka umum atau lelang, Hal ini mengingat bahwa pelaksanaan amar putusan berupa kewajiban pembayaran sejumlah uang oleh pihak tereksekusi kepada pihak pemohon eksekusi, sebagaimana yang menjadi tujuan utama dari eksekusi perdata, sangat tergantung dari berhasil atau tidaknya penjualan objek sita eksekusi melalui proses lelang tersebut yang memberikan rasa keadilan bagi semua pihak yang terlibat dalam proses pelaksanaan lelang, terutama pembeli dan penjual lelang. Tentunya dapat dibayangkan jika pada suatu kasus dimana sita terhadap objek eksekusi telah dinyatakan sah dan berharga, namun objek tersebut tidak kunjung terjual sebagai akibat dari proses pelaksanaan eksekusi yang tidak adil (unfair) dan di rekayasa.

Pasal 1 Peraturan Menteri Keuangan No. 304/KMK 01/2002 tetang Petunjuk Pelaksanaan Lelang, yang diterbitkan tanggal 30 Mei 2006 menyebutkan bahwa: "Lelang adalah penjualan barang yang terbuka untuk umum dengan penawaran harga secara tertulis 
dan/atau lisan yang semakin meningkat atau menurun untuk mencapai harga tertinggi yang didahului dengan pengumuman lelang,"20

a. Dasar Hukum Pelaksanaan Lelang eksekusi

Disamping itu, dasar hukum pelaksanaan lelang yang masih berlaku di Indonesia cukup banyak, mulai dari peraturan peninggalan kolonial yang dterjemahkan, sampai peraturan yang bersifat sangat teknis yang dikeluarkan oleh instansi terkait seperti Peraturan Dirjen Piutang Lelang Negara Departemen Keuangan. ${ }^{21}$ Peraturan-peraturan sebagaimana di maksud yaitu:

1) Pasal 200 Ayat (1) HIR/216
Rbg.
2) Peraturan Lelang (vendu regelement), Lembaran Negara (LN) 1908 No.189 sebagaimana diubah dengan Stb. 1940 No. 56.

3) Instruksi Lelang (vendu instructie) LN 1908 No. 190, sebagaimana telah diubah dengan LN 1949 No. 390.

4) Peraturan Pemungutan Bea Lelang untuk Pelelangan dan Penjualan Umum (vendu salaris) LN 1949 No. 390.

5) Peraturan Menteri Keuangan No. 102/PMK.01/2008 Tentang Organisasi dan Tata Kerja Instansi Vertikal Direktorat Jenderal Kekayaan Negara.

\footnotetext{
${ }^{20}$ Bandingkan dengan definisi pada ketentuan yang berlaku sebelumnya yaitu Pasal 1 KMK 2002 Tentang Petunjuk Pelaksanaan Lelang "Lelang adalah penjualan barang yang terbuka untuk umum baik secara langsung maupun melalui media elektronik dengan cara penawaran harga lisan dan atau tertulis yang didahului dengan usaha mengumpulkan peminat".

${ }^{21}$ Sekarang Direktorat Jenderal Kekayaan Negara (DJKN) Departemen Keuangan RI.
}

6) Peraturan Menteri Keuangan No. 40/PMK.07/2006 tetang Petunjuk Pelaksanaan Lelang, diterbitkan Tanggal 30 Mei 2006. Sebagaimana beberapa kali diubah terakhir dengan Peraturan Menteri Keuangan No. 61/PMK.06/2008.

7) Peraturan Menteri Keuangan No. 41/PMK.07/2006 Tentang Pejabat Lelang Kelas I. diterbitkan Tanggal 30 Mei 2006.

8) Peraturan Menteri Keuangan No.118/PMK.07/2005 Tentang Pejabat Lelang Kelas II.

9) Peraturan Menteri Keuangan No. 119/PMK.07/2005 Tentang Balai Lelang.

10) Peraturan DJPLN No. PER01/PL//2006 Tentang Pedoman Administrasi Perkantoran dan Pelaporan Kantor Pejabat Lelang Kelas II. diterbitkan Tanggal 30 Juni 2006.

11) Peraturan DJPLN No. PER/02/PL/2002 Tentang Petunjuk Teknis Pelaksanaan Lelang..

12) Peraturan DJKN No. PER06/KN/2009 Tentang Pedoman Administrasi Perkantoran dan Laporan Lelang oleh KPKNL.

b. Jenis-jenis Lelang Eksekusi yang diselaenggarakan oleh KPKNL

Pada prinsipnya leleng yang dilaksanakan oleh KPKNL dan atau Balai Lelang hanya 3 (tiga), yaitu lelang eksekusi, lelang non eksekusi wajib, dan lelang non eksekusi sukarela. Sedangkan lelang eksekusi putusan pengadilan (perkara perdata) yang menjadi fokus penelitian ini termasuk ke dalam pengertian lelang eksekusi, disamping masih ada beberapa jenis lelang eksekusi lainnya sebagaimana yang 
disebutkan pada Pasal 1 angka (4) Peraturan Menteri Keuangan No. 40/PMK.07/2006.

Pengertian Lelang Eksekusi adalah lelang untuk melaksanakan putusan/penetapan pengadilan atau dokumen-dokumen lain, yang sesuai dengan peraturan perundangundangan yang berlaku, dipersamakan dengan itu, dalam rangka membantu penegakan hukum, antara lain:

1) Lelang eksekusi PUPN;

2) Lelang eksekusi pengadilan;

3) Lelang eksekusi Pajak;

4) Lelang eksekusi Harta Pailit;

5) Lelang eksekusi Pasal 6 UUHT;

6) Lelang eksekusi dikuasai/tidak dikuasai Bea Cukai;

7) Lelang eksekusi Barang Sitaan Pasal 45 KUHAP;

8) Lelang eksekusi Barang rampasan;

9) Lelang eksekusi barang temuan;

10) Lelang eksekusi Fidusia;

11) Lelang eksekusi gadai.

Pejabat lelang yang berwenang melakukan semua jenis lelang diatas adalah Pejabat lelang Kelas I yang berkedudukan di $\mathrm{KPKNL}^{22}$ hal ini mengingat bahwa kewenangan yang diberikan kepada Pejabat Lelang Kelas II hanya terbatas pada jenis lelang yang dilaksanakan atas permohonan Balai Lelang yang berbentuk badan hukum selaku mitra KPKNL dalam melaksanakan lelang, ${ }^{23}$ sedangkan kewenangan Pejabat lelang Kelas II yang diberikan oleh peraturan

${ }^{22}$ Lihat Pasal 5 Peraturan Menteri Keuangan No. 41/PMK.07/2006 Tentang Pejabat Lelang Kelas I.

${ }^{23}$ Lihat Pasal 2 Peraturan Menteri Keuangan No. 119/PMK.07/2005 Tentang Balai Lelang.
Perundang-undangan hanya meliputi: ${ }^{24}$

1) Lelang non eksekusi sukarela;

2) Lelang aset BUMN/D berbentuk Persero; dan

3) Lelang aset milik bank dalam likuidasi berdasarkan Peraturan Pemerintah Nomor 25 Tahun 1999 tentang Pencabutan Izin Usaha, Pembubaran dan Likuidasi Bank.

\begin{tabular}{lrr}
\multicolumn{2}{c}{ Berdasarkan } & Peraturan \\
Menteri & Keuangan & No. \\
100/PMK.01/2008 & Tentang \\
Organisasi dan Tata & Kerja
\end{tabular}
Departemen Keuangan, sebagaimana telah beberapa kali diubah terakhir dengan Peraturan Menteri Keuangan No.73/PMK.01/2009. Serta Peraturan Menteri Keuangan No. 102/PMK.01/2008 tentang Organisasi dan Tata Kerja Instansi Vertikal Direktorat Jenderal Kekayaan Negara. Kantor lelang Negara yang semula bernama KP2LN berubah menjadi KPKNL dan merupakan bagian dari Direktorak Kekayaan Negara Departemen Keuangan RI.
c. Mekanisme Pelaksanaan Lelang Eksekusi Pengadilan oleh KPKNL

Sebagaimana telah kita lihat di atas, bahwa begitu banyaknya dasar hukum terkait dengan pelaksanaan lelang baik lelang eksekusi maupun non eksekusi, dan mayoritas peraturan-peraturan tersebut adalah produk hukum dari Departemen Keuangan yang ditunjuk oleh pemerintah sebagai pihak yang berwenang sebagai penyususn kebijakan terkait dengan pelaksanaan lelang. Mengingat bahwa lelang

\footnotetext{
${ }^{24}$ Lihat Pasal 9 Peraturan Menteri Keuangan No.118/PMK.07/2005 Tentang Pejabat Lelang Kelas II.
} 
eksekusi hanya dapat dilaksanankan oleh Pejabat Lelang Kelas I di KPKLN, maka, mekanisme pelaksanaan lelang eksekusi berpedoman pada Peraturan Menteri Keuangan No. 40/PMK.07/2006 tetang Petunjuk Pelaksanaan Lelang sebagaimana beberapa kali diubah terakhir dengan Peraturan Menteri Keuangan No. 61/PMK.06/2008, Peraturan Menteri Keuangan No. 41/PMK.07/2006 Tentang Pejabat Lelang Kelas I. dan secara lebih teknis diatur oleh peraturan direktorat jenderal yaitu: Peraturan DJPLN No. PER/-02/PL/2002 Tentang Petunjuk Teknis Pelaksanaan Lelang serta Peraturan DJKN No. PER-06/KN/2009 Tentang Pedoman Administrasi Perkantoran dan Laporan Lelang oleh KPKNL

1) Permohonan dan syaratsyarat lelang eksekusi pengadilan

Mengingat setiap

pelaksanaan lelang wajib dilakukan oleh/dihadapan pejabat lelang baik Pejabat Lelang Kelas I maupun II, maka semua prosedur pelaksanaan lelang harus diawali dengan permohonan secara tertulis kepada Kepala KPKNL dan atau Pimpinan Balai Lelang disertai dengan dokumen-dokumen persyaratan lelang. Sepanjang persyaratan pelaksanaan lelang tersebut telah lengkap dan memenuhi legalitas subjek dan objek lelang, kedua lembaga tersebut tidak boleh menolak permohonan lelang yang diajukan kepadanya. Khusus untuk lelang eksekusi pengadilan, lelang hanya dapat dilaksanakan oleh Pejabat Lelang Kelas I, maka permohonan sebagaimana dimaksud hanya dapat diajukan oleh Ketua
Pengadilan Negeri selaku Pemohon Lelang kepada Kepala KPKNL di wilayah kerja tempat objek lelang berada.

Pelaksanaan lelang diawali
dengan adanya
PERMOHONAN
LANJUT TINDAK
EKSEKUSI yang diajukan pemohon
eksekusi kepada Ketua Pengadilan
Negeri setempat, kemudian atas
dasar surat tersebut Ketua
Pengadilan Negeri membuat SURAT PENETAPAN PELAKSANAAN LELANG EKSEKUSI yang memerintahkan kepada Panitera untuk mengajukan SURAT PEMBERITAHUAN

PELAKSANAAN LELANG dan SURAT PERMOHONAN LELANG EKSEKUSI yang ditujukan kepada Kepala Kantor Pelayanan Kekayaan Negara dan Lelang (KPKNL) setempat, serta melengkapi berkas persyaratan pelaksanaan lelang eksekusi pengadilan, sebagaimana yang disebutkan pada Pasal 6 angka (2) Peraturan DJPLN No. PER/02/PL/2002 Tentang Petunjuk Teknis Pelaksanaan Lelang berupa:

a) Salinan/fotokopi Putusan dan/atau Penetapan Pengadilan yang sudah mempunyai kekuatan hukum tetap dan mengikat (in kracht van gewisjde).

b) Salinan/fotokopi Penetapan/aanmaning/tegura n kepada tereksekusi dari Ketua Pengadilan.

c) Salinan/fotokopi Penetapan sita oleh Ketua Pengadilan.

d) Salinan/fotokopi Berita Acara Sita;

e) Salinan/fotokopi perincian hutang/jumlah kewajiban tereksekusi yang harus dipenuhi; 
f) Salinan/fotokopi pemberitahuan lelang kepada termohon eksekusi; dan

g) Asli dan/atau fotokopi bukti kepemilikan/hak, apabila berdasarkan peraturan perundang-undangan diperlukan adanya bukti kepemilikan/hak, atau apabila bukti kepemilikan/hak tidak dikuasai, harus ada pernyataan tertulis/surat keterangan dari penjual bahwa barang-barang tersebut tidak disertai bukti kepemilikan/hak dengan menyebutkan alasannya.

2) Surat Keterangan Pendaftaran Tanah (SKPT)

Mengingat bahwa barang milik tereksekusi yang akan dilelang dapat berupa benda bergerak maupun tidak bergerak (tetap) yang dimiliki secara sah oleh tereksekusi, maka, adanya hak tersebut harus dibuktikan dengan dokumen bukti kepemilikan/hak terhadap objek yang akan di lelang. Sedangkan khusus untuk objek lelang tanah dan bangunan, baik yang telah bersertifikat ataupun belum, sebagai syarat untuk dapat dilaksanakannya lelang harus melampirkan Surat keterangan tanah (SKT) yang dikeluarkan oleh Badan Pertanahan Nasional setempat. Penerbitan SKPT oleh BPN setempat tersebut didasarkan pada SURAT PERMOHONAN PENERBITAN SKPT yang dibuat oleh KPN melalui Panitera Pengadilan Negeri dan ditujukan kepada Kantor Pertanahan setempat.

3) Penentuan Nilai Limit dan Uang Jaminan Lelang

Uang jaminan ditentukan oleh penjual/pemilik barang dengan perhitungan minimal $20 \%$ dan maksimal 50\% dari perkiraan harga limit. Sedangkan khusus lelang eksekusi, besaran harga limit tesebut harus bersifat terbuka dan dicantumkan pada pengumuman lelang. Sedangkan penyetoran uang jaminan penawaran tersebut disetorkan kepada bendahara penerima di KPKNL paling lambaat 1 (satu) hari sebelum pelaksanaan lelang melalui rekening yang sudah ditetapkan pada pengumuman lelang yang bersangkutan.

4) Pengumuman Lelang dan Bea Lelang

Berdasarkan Pasal 1 angka (3) Peraturan Menteri Keuangan No. 40/PMK.07/2006 yang dimaksud dengan pengumuman lelang adalah pemberitahuan kepada masyarakat tentang akan adanya lelang dengan maksud untuk menghimpun peminat lelang dan pemberitahuan kepada pihak yang berkepentingan.

Sedangkan mengenai kewajiban pembayaran biaya-biaya yang harus dikeluarkan terhadap pelaksanaan lelang dibebankan kepada peserta lelang yang disahkan sebagai pembeli, biaya-biaya yang wajib dibayar tersebut yatu:

1. Harga lelang

2. Bea lelang

3. Pungutan lain yang diatur berdasarkan peraturan perundangan yang berlaku

Tidak dipenuhi kewajiban di atas akan berakibat dapat dibatalkannya status sebagai pembali yang sah oleh panitia lelang, karena pembatalan lelang dapat dilakukan apabila pembeli ingkar untuk membayar hingga melewati batas pembayaran terakhir, yakni setelah mendapatkan Surat Peringatan Terakhir, kemudian Pejabat 
Lelang mengeluarkan Pernyataan Pembatalan.

\section{Prosedur Pelaksanaan Eksekusi Putusan Pengadilan dalam Perkara Perdata Pada Tahap Pasca Lelang (Pelaksanaan Eksekusi Pengosongan Objek Lelang)}

Jenis eksekusi yang sering menimbulkan masalah di dalam praktek adalah eksekusi pengosongan terhadap benda tidak bergerak milik termohon eksekusi berupa tanah, rumah, ruko, pabrik, kantor dam sebagainya. Di dalam praktik sering ditemukan fakta bahwa meskipun termohon eksekusi telah mengakui kekalahannya di dalam putusan pengadilan dan mengetahui barang miliknya telah di beli secara sah oleh pihak ketiga melalui proses penjualan lelang yang sah, namun kenyataannya termohon eksekusi atau ahli warisnya tetap tidak mau pindah dan mengosongkan barang-barang milikinya. Bahkan sering sekali terjadi bahwa termohon eksekusi, ahli warisnya, dan pihak yang tidak berkepentingan sengaja diperintahkan oleh pemohon eksekusi untuk menduduki benda bergerak yang bersangkutan dan tujuannya tetap ingin menguasai benda yang secara hukum bukan miliknya lagi, bahkan sering disertai perlawanan. Dengan demikian, untuk melindungi pembeli lelang yang beritikad baik, dilakukan eksekusi pengosongan untuk kepentiangan dan atas biaya pembeli lelang.

Pelaksanaan eksekusi pengosongan tersebut atas perintah KPN dan dilaksanakan dengan tahapan-tahapan sebagai berikut:

a. Pembeli lelang yang sah mengjukan

SURAT
PERMOHONAN

EKSEKUSI

PENGOSONGAN kepada

Ketua Pengadilan Negeri setempat.

b. Ketua Pengadilan Negeri melalui SURAT

PENETAPAN EKSEKUSI PENGOSONGAN

memetintahkan kepada

Panitera atau Jutu Sita untuk

melakukan eksekusi

pengosongan.

c. Panitera memberikan

pemberitahuan kepada

termohon eksekusi melalui

SURAT

PEMBERITAHUAN

PELAKSANAAN

EKSEKUSI

PENGOSONGAN bahwa

akan dilakukan eksekusi

pengosongan terhadap benda

tidak bergerak miliknya, serta

diberitahukan bahwa dalam

waktu 7 (tujuh) hari sebelum pengosongan dilaksanakan, untuk secara sukarela mengosongkan dan memindahkan barang-barang miliknya ketempat lain. Apabila pihak tereksekusi tidak hadir maka juru sita tetap melaksanakan penyitaan secara paksa. Namun dalam praktek pihak tereksekusi hadir pada saat penyitaan, bahkan tidak segan-segan melakukan perlawanan kepada juru sita.

d. Panitera membuat SURAT PERMOHONAN

BANTUAN ditujukan kepada Kepala Desa/Lurah setempat, Camat, Kepala Kepolisian Negara RI Resort (KAPOLRES) cq. Bagian Operasional dan selanjutnya 
diteruskan kepada Kepala Kepolisian Sektor

(KAPOLSEK) setempat.

e. Panitera membuat SURAT PANGGILAN RAPAT KOORDINASI kepada para pihak yang terkait yaitu Lurah/Kepada Desa, Camat, pihak Kepolisiann guana kelancaran tugas pelaksanaan eksekusi pengosongan.

\section{Permasalahan Eksekusi Perdata Terkait Hambatan Penjualan Objek Lelang Eksekusi}

Permasalahan yang sering muncul di dalam praktek terkait hambatan penjualan objek lelang eksekusi adalah tidak kunjung terjualnya objek lelang/lelang tidak ada peminat yang disebabkan oleh beberapa hal. Dalam hal pelaksanaan lelang tidak ada penawaran sebagaimana tersebut di atas, maka pejabat lelang mengeluarkan surat keputusan untuk dilakukan lelang ulang, yang di dasarkan pada SURAT PERMOHONAN LELANG ULANG yang diajukan oleh Pemohon Lelang kepada Kantor Lelang. Namun dalam hal meskipun lelang ulang telah beberapa kali di laksanakan dan objek eksekusi belum juga terjual, di dalam praktek, menurut keterangan nara sumber Karma Herawati yang menjabat sebagai Panitera Muda Bidang Perdata PN Kelas IA Tanjung Karang, biasanya solusi yang dapat di tempuh adalah:

a. Pemurunan Nilai limit secara bertahap sehingga tercapai harga pembeli tertinggi, dan pelaksanaan lelang ulang sebagaimana dimaksud dapat dilaksanakan meskupun hanya diikuti 1 (satu) peserta lelang. b. Melaksanakan eksekusi pengosongan terlebih dahulu oleh pemohon eksekusi, mengingat biasanya peminat lelang tidak dapat melihat dan meneliti objek lelang karena masih dikuasai oleh pemiliknya. Dengan demikian, solusi yang dapat diambil adalah melakukan eksekusi pengosongan terlebih dahulu sebelum dilaksanakan penjualan lelang. Sedangkan biaya eksekusi pengosongan tersebut sementara dibayar oleh pemohon eksekusi yang nantinya akan digantikan sejumlah uang yang dikeluarkan tersebut oleh termohon eksekusi pada saat objek lelang telah secara sah terjual.

\section{Permasalahan Eksekusi Perdata Terkait Hambatan Pelaksanaan Pengosongan Objek Lelang}

Setelah membahas mengenai permasalahan-permasalahan eksekusi perdata dalam kaitannya dengan penjualan objek lelang. Pada sub bab ini akan dibahas mengenai fungsi, peranan, serta koordinasi antara Pengadilan Negeri, KPKNL, serta POLRI dalam mengatasi hambatanhambatan pelaksanaan eksekusi di dalam praktik, khususnya dalam hal terjadi:

a. Pihak tereksekusi tidak mau melakukan pengosongan objek eksekusi.

Dalam menjalankan tugasnya seringkali juru sita menghadapi beberapa hambatan karena antara praktik dan teori kadang berbeda. Munculnya hambatan dalam praktek menyulitkan juru sita ketika menjalankan tugas di lapangan. Menurut keterangan yang diberikan oleh Amir Hamzah yang menjabat 
sebagai Juru Sita Pengadilan Negeri Kelas IA Tanjung Karanng bahwa apabila pihak tereksekusi tetap menolak dilaksanakannya pengosongan terhadap objek eksekusi, maka upaya paksa tetap di laksanakan, dengan tahapan sebagai berikut:

1) Pemberitahuan yang diberikan kepada pihak tereksekusi 7 (tujuh) hari sebelum dimulainya eksekusi.

2) Setelah mendapatkan perintah eksekusi oleh ketua Pengadilan Negeri maka juru sita melaksanakan koordinasi dengan pihak kepolisian dengan mengajukan SURAT PERMOHONAN BANTUAN PENGAMANAN yang ditujukan kepada Kepala Kepolisisan Negara RI Resort/Kota Besar tempat dimana objek eksekusi berada cq. Kepala Bagian Operasional Kepolisian, yang selanjutnya di lanjutkan ke Kepala Kepolisisan Negara RI Sektor (KAPOLSEK) setempat dimana akan dilaksanakannya sita eksekusi. Sedangkan jumlah personel pengamanan ditentukan oleh KAPOLSEK setempat disesuaikan dengan tingkat keamanan di tempat penyitaan. Meskipun pada pasal 200 (11) HIR di nyatakan pihak polisi dapat dimintakan bantuan apabila jika diperlukan, namun dalam praktek jarang sekali ditemukan Juru Sita melaksanakan penyitaan tanpa ada bantuan dari pihak kepolisian karena alasan keamanan dan seringkali pihak tereksekusi tetap melakukan perlawanan untuk mempertahankan objek sengketa. Peranan kepolisian dalam proses pelaksanaan sita pengosongan tersebut dibuktikan dengan ikut sertanya wakil dari pihak kepolisian dalan menandatangani Berita Acara Pengosongan setelah eksekusi penyitaan selesai dilaksanakan.

3) Kemudian sesuai dengan tugas juru sita yakni memberikan salinan resmi berita acara eksekusi kepada pihak yang berkepentingan.

b. Pendudukan Kembali objek eksekusi adalah Tindak Pidana

Pada kasus perampasan dan atau pendudukan kembali objek eksekusi oleh pihak tereksekusi. Apabila eksekusi pengosongan telah dilaksanakan dan pengumuman yang menyatakan objek sengketa telah di taruh tempat tersebut maka objek sengketa tersebut tidak diperbolehkan ditempati kembali. Apabila objek sengketa tersebut ditempati kembali oleh pihak tersengketa atau pihak-puhak lain yang bukan haknya maka dapat diketagorikan sebagai tindak pidana. Dan pihak kepolisian berwenang melaksanakan upaya paksa sesuai hokum acara pidana yang berlaku terhadap para pihak yang berusaha menghalangi upaya sita eksekusi. Demikian juga halnya dengan penjualan, penyewaan, dan pengalihan objek sita eksekusi oleh pihak tereksekusi.

\section{Penutup}

Tahapan akhir dari rangkaian proses acara perdata tidak hanya menghasilkan putusan yang adil dan berkekuatan hukum tetap, namun sampai dengan dilaksanakannya amar putusan oleh pihak yang kalah 
secara sukarela. Di dalam praktek sering terjadi bahwa pihak yang kalah tersebut tidak melaksanakan kewajibannya memenuhi amar putusan, sehingga diperlukan upaya paksa untuk memenuhinya.berdasarkan jenis amar putusannya, eksekusi putusan pengadilan dapat dibedakan menjadi dua yaitu: eksekusi riil dan eksekusi pembayaran sejumlah uang. Sedangkan dua jenis eksekusi lain yaitu ekskusi melakukan perbuatan yang dapat dinilai dengan uang dan eksekusi pengosongan, namun keduanya dikategorikan sebagai eksekusi riil.

Pada prinsipnya tahapan pelaksanaan eksekusi putusan pengadilan dari setiap jenis eksekusi adalah sama, yaitu harus melalui Permohonan dari pemohon eksekusi, Penetapan Ketua Pengadilan Negeri setempat dan pelaksanannya harus dibuatkan dengan Berita Acara. namun khusus eksekusi pembayaran sejumlah uang, harus melewati tahap Penjualan Lelang yang dilakukan oleh Pejabat Lelang Kelas I di Kantor Pelayanan Kekayaan Negara dan Lelang setempat.

Permasalahan yang sering muncul dalam proses eksekusi adalah pada tahap penjualan lelang, dimana tidak kunjung terjualnya objek lelang sehingga pelaksanaan eksekusi menjadi tertunda yaitu Pertama, keadaan dimana lelang tidak ada peminat/penawaran karena tingginya nilai limit objek lelang. Solusi yang dapat ditempuh adalah pemohon eksekusi membuat surat permohonan kepada Ketua Pengadilan Negeri setempat untuk menurunkan nilai limit objek lelang secara bertahap sampai tercapai harga pembeli tertinggi. Permasalahan kedua yang menyebabkan tidak kunjung terjualnya objek lelang tersebut disebabkan oleh masih didudukinya objek lelang oleh pihak tereksekusi yang melakukan perlawanan sehingga calon pembeli lelang tidak dapat meneliti/melihat objek lelang yang akan dibelinya, sehingga tidak berminat membeli objek lelang. Solusi yang dapat diambil adalah pelaksanaan eksekusi pengosongan terlebih dahulu terhadap objek lelang, dan setelah objek lelang terjual pembeli lelang menggati biaya-biaya yang telah dikeluarkan oleh pemohon lelang dalam pelaksanaan eksekusi pengosongan tersebut. Pada pelaksanaan eksekusi pengosongan koordinasi antara pihak Pengadilan, Lurah setempat dan Kepolisian mutlak diperlukan guna kelancaran proses eksekusi pengosongan. Demikian halnya dengan terjadinya pendudukan kembali objek lelang oleh pihak tereksekusi dapat dikualifikasikan sebagai tindak pidana dan akan diproses berdasarkana hokum acara pidana yang berlaku.

\section{Daftar Pustaka}

A. Muhammad Asrun. Krisis Peradilan; Mahkamah Agung dibawah Soeharto. (Jakarta: ELSAM, 2003).

Bagir Manan. Sistim Peradilan Berwibawa; Suatu Pencarian. (Yogyakarta: UII Press, 2005).

Wakil Ketua MA diduga Intervensi Penetapan Eksekusi. www.hukumonline.com diakses tanggal 19 Februari 2008.

Subekti. Hukum Acara Perdata. (Jakarta: BPHN, 1977).

Retnowulan Sutantio dan Oeripkartawinata. Hukum 
Acara Perdata dalam Teori dan Praktek (bandung:

Alumni, 1979).

M. Yahya Harahap. Ruang Lingkup Permasalahan Eksekusi Bidang Perdata. ed. II. cet. II (Jakarta: Sinar Grafika, 2006).

R. Soesilo. RIB/HIR dengan penjelasan (Bogor: Politeia, 1995).

Abdulkadir Muhammad. Hukum Acara Perdata. cet. VII. (Bandung: PT. Citra Aditya Bakti, 2000).

Sudikno Mertokusumo, Hukum Acara Perdata Indonesia .ed. V. cet.I. (Yogyakarta: Penerbit Liberty, 1998).

Ny. Arie S. Hutagalung. Praktek Pembebanan dan Pelaksanaan Eksekusi Hak Tanggungan di Indonesia (Jurnal Hukum dan Pembangunan Tahun Ke-38 No. 2. April-Juni 2008).

Republik Indonesia, Undang Undang No. 4 Tahun 2004 tentang Kekuasaan Kehakiman; Undang Undang

No. 2 Tahun 1986 tentang Peradilan Umum; ,Undang-undang No.

28 Tahun 1997 Tentang Kepolisian Negara Republik Indonesia.

Kitab Undang-undang Hukum

Perdata (Burgerlijk Wetboek/BW);

Herzeine Indisce Regelemen (HIR), (Stbld. No. 52/1847). dan Rechtsregelement voor de Buitengewesten (Rbg), (stbld No.227 Tahun 1927);

Regelement op de Burgerlijk Rechtvordering (B. Rv/Rv), (Stbld. No. 52/1847).

Peraturan Lelang (vendu regelement), Lembaran Negara (LN) 1908 No.189 sebagaimana diubah dengan Stb. 1940 No. 56.

Instruksi Lelang (vendu instructie) LN 1908 No. 190, sebagaimana telah diubah dengan LN 1949 No. 390.

Peraturan Pemungutan Bea Lelang untuk Pelalangan dan Penjualan Umum (vendu salaris) LN 1949 No. 390.

Keputusan Menteri Keuangan No. 304/KMK 01/2002 tetang Petunjuk Pelaksanaan Lelang, yang diterbitkan tanggal 13 Juni 2002.

Keputusan Menteri Keuangan No. 450/KMK 01/2002 tentang Perubahan atas Keputusan Menteri Keuangan No. 304/KMK 01/2002 tetang Petunjuk Pelaksanaan Lelang.

Keputusan Menteri Keuangan Nomor 445/KMK.01/2001 tentang Organisasi dan Tata Kerja Kantor Wilayah Direktorat Jenderal Piutang dan Lelang Negara dan Kantor Pelayanan Piutang dan Lelang Negara;

Keputusan Menteri Keuangan No. 305/KMK.01/2002 tentang Pejabat Lelang.

Keputusan Menteri Keuangan No. 451/KMK.01/2002; Tentang

Perubahan Keputusan Menteri

Keuangan Nomor

305/KMK.01/2002 tentang

Pejabat Lelang.

Keputusan Menteri Keuangan No. 41/PMK.07/2006 Tentang

Pejabat Lelang Kelas I.

Keputusan DJPLN No. 35/PL/2002

Tentang Petunjuk Teknis

Pelaksanaan Lelang.

Keputusan DJPLN No. 36/PL/2002

Tentang Petunjuk Teknis

Pejabat Lelang. 
Fiat Justitia Jurnal Ilmu Hukum Volume 6 No. 2 Mei-Agustus 2012, ISSN 1978-5186 